\title{
A phylogenetic study on Scenedesmaceae with the description of a new species of Pectinodesmus and the new genera Verrucodesmus and Chodatodesmus (Chlorophyta, Chlorophyceae)
}

\author{
Eberhard Hegewald ${ }^{1 *}$, Christina BocK ${ }^{2} \&$ Lothar KRIENITZ ${ }^{3}$
}

\author{
${ }^{1}$ D-52382 Niederzier, Grüner Weg 20, Germany; *Corresponding author e-mail: e.hegewald@googlemail.com \\ ${ }^{2}$ University Duisburg-Essen, Department General Botany, Universitätsstr. 5, D-45141 Essen, Germany \\ ${ }^{3}$ Leibniz-Institute of Freshwater Ecology and Inland Fisheries, D-16775 Stechlin-Neuglobsow, Germany
}

\begin{abstract}
A comparative study of the phylogeny of Scenedesmaceae based on rRNA gene sequences (ITS1/5.8S/ITS2), cell morphology and cell wall ultrastructure resulted in the acceptance of the genus Acutodesmus and the description of the new genera Verrucodesmus and Chodatodesmus. A new species Pectinodesmus holtmannii and 11 new combinations were erected: Chodatodesmus mucronulatus, Verrucodesmus verrucosus, V. parvus, Pectinodesmus pectinatus f. tortuosus, Acutodesmus bajacalifornicus, A. bernardii, A. deserticola, A. dissociatus, A. distendus, A. nygaardii, A. obliquus var. dactylococcoides. It was shown that the new genera Verrucodesmus and two of the Chodatodesmus strains have enlarged ITS2 helices (helix I in Verrucodesmus and helix III in Chodatodesmus). The occurrence of zoospores of Scenedesmaceae in nature was discussed.
\end{abstract}

Key words: Acutodesmus, Chlorophyta, Chodatodesmus, 5.8S, ITS1, ITS2, Pectinodesmus, Scenedesmaceae, Taxonomy, Verrucodesmus, zoospores

\section{INTRODUCTION}

The genus Scenedesmus was interpreted in a broad sense that included many species with very different morphological characters (e.g. MeYen 1829; Сhodat 1926; Sмith 1916; КомÁreK \& FotT 1983). In particular, HortobáGYi (e.g. 1960) described many taxa using light microscopic studies of natural material. A better understanding of the taxa was achieved using cultured material (e.g. СHоDAт 1913, 1926; SмIтH 1916; Ahlstrom 1934; Trainor 1964; Hegewald 1982, 1989; KRIENITZ 1987; Hegewald et al. 1990; HindÁK 1990; Holtmann 1994; Tsarenko et al. 2006). The morphological variability was further revealed with electron microscopic studies (e.g. Hegewald et al. 1990; Hegewald \& Schnepf 1991; Hegewald \& AN 1998; TSARENKO et al. 2005; VANORMELINGEN et al. 2007; FAWLEY et al. 2011). Taxa from other genera were transferred to Scenedesmus sensu lato (e.g. as in KomÁrek \& FotT (1983), or e.g. Chlo-rella fusca ShiHira et R.W. Krauss (Hegewald 1982). The transfer of the latter to Scenedesmus was verified using molecular data by KessLer et al. (1997). For further examples, see Hegewald \& Silva (1988). With the shift of genera or taxa to or from the Scenedesmaceae the delineation of genera and species in that family became more difficult, and molecular phylogenetic studies added more complexity because morphological and molecular data were not always in agreement (KRIENITZ et al. 2003).

Subgenera of Scenedesmus were first erected by Chodat (1926) (see also Kiriakov 1976; Hegewald 1978). Based upon electron microscopy, the mainly spiny species of the subgenus Desmodesmus were characterized by a unique outer cell wall ultrastructure of an additional algenean layer (HEGEWALD 1997). The genera Acutodesmus, Coelastrum, Enallax, Scotiella, Scotiellopsis and Pectinodesmus were characterized by longitudinal or net-like ridges produced by the inner cellulosic cell wall (e.g. Hegewald et al. 2010; Punčocháŕová \& Kalina 1981; Kalina \& Punčochár̆ová 1987; TschaiKner et al. 2007). Subgenus Acutodesmus was revised in KomÁrek \& Fотт (1983) and a set of strains was studied using light microscopy (HeGeWald 1982, 1989; KRIENITZ 1987; Holtmann 1994). The revision by Holtmann (1994) involved many strains and some new combinations were made; however, the extensive morphological variability led to taxonomic lumping (HoLTMANN \& Hegewald 1986; Hegewald 1989; Holtmann 1994). Finally, the subgenus Scenedesmus was limited to species with obtuse cells without cell wall structures embedded in mucilage. Few taxa are exceptional in having granulated cell walls. However, the granulation was not a wall structure but an unknown precipitate (Hegewald et al. 1988).

The first DNA studies for Scenedesmaceae were carried out by Paschma \& Hegewald (1986). 
The nuclear-encoded rRNA internal transcribed spacer region (ITS2) sequences were published by An et al. (1999), KitschKe (2001), van Hannen et al. (2002), Lewis \& Flechtner (2004), Johnson et al. (2007), Hegewald et al. (2010), Eliáš et al. (2011) and Buchieim et al. (2011). The An et al. (1999) study showed two clear clades for Scenedesmus sensu lato; the first contained the subgenus Desmodesmus which subsequently was raised to genus level and the second clade contained the remaining Scenedesmus taxa. The subgenus Acutodesmus was raised to a genus by Tsarenko \& Petlevanny (2001); however, the new genus was not always accepted (e.g. HegewALd \& WolF 2003; Hegewald et al. 2010). Finally, Pectinodesmus and Comasiella were separated from Scenedesmus sensu lato (Hegewald et al. 2010). In this paper we studied a large set of strains representing the genera Pectinodesmus, Acutodesmus and Scenedesmus sensu lato for a better understanding of the taxonomy of this group.

\section{Material and Methods}

Strains were obtained from the Culture Collection of Algae and Protozoa (CCAP, Oban, UK) and the algal collection, Leibniz-Institute of Freshwater Ecology and Inland Fisheries Stechlin-Neuglobsow, Germany. СноDAт strains were from the collection at Geneve, Switzerland; this collection was closed years ago, and some CHODAT strains were maintained at the Research Center Jülich, Germany. The strain collection of the Research Center Jülich then closed, and the cultures were deposited in CCAP and CHODAT strains in the Sammlung von Algenkulturen Göttingen (SAG, Göttingen, Germany). Strains were grown in a modified Bourrelly Medium (Hegewald et al. 1994; Krienitz \& WirTh 2006). For scanning electron microscopy (SEM), cells were fixed with formaldehyde or glutaraldehyde, dehydrated in 20,40 , 60,80 and $100 \%$ acetone, critical-point dried and sputtered with gold. SEM images were taken with a JEOL 6300F.

Total Genomic DNA was isolated using a lysozyme/ sodium phosphate method modified from Somerville et al. (1989). Algal cells were mechanically disrupted using the Tissuelyser II (Qiagen, Hilden, Germany) in the presence of glass beads and suspended in $600 \mu \mathrm{l}$ sodium-phosphate buffer $(120 \mathrm{mM})$ and $100 \mu \mathrm{l} \operatorname{SDS}(25 \% \mathrm{w} / \mathrm{v})$. After centrifugation, the solution was incubated with $200 \mu$ lysozyme for 1 hour at $37^{\circ} \mathrm{C}$. The mixture was incubated over night $\left(55^{\circ} \mathrm{C}\right)$ after adding $12.5 \mu \mathrm{l}$ proteinase $\mathrm{K}$ and $150 \mu \mathrm{l}$ SDS (25\%). The nucleic acids were purified by ammonium acetate treatment ( 0.5 volumes of $7.5 \mathrm{M}$ ammonium acetate incubated on ice for $5 \mathrm{~min}$ ) followed by a centrifugation step with 0.7 volumes of isopropanol for $1 \mathrm{~h}$. The precipitated pellet was washed two times with $80 \%$ ethanol and resuspended in $150 \mu \mathrm{TE}-$ Buffer. The polymerase chain reactions (PCR), purification and sequencing for the ITS rRNA gene was carried out after Bock et al. (2011). The ITS partial sequences of each strain were assembled to a complete consensus sequence using the software SeqAssam (Hepperle 2004). The sequences were manually aligned according to their secondary structure with the SequentiX Alignment Editor (Hepperle 2004). For the phylogenetic analyses, two different datasets were composed. For the ITS2 analyses, a dataset of 80 taxa with 401 aligned bases was constructed, using two members of the Pediastrum-clade as outgroup. For the ITS1 dataset, 59 taxa with 289 characters were aligned. The alignments were analyzed by distance (neighbor joining; $\mathrm{NJ}$ ) and maximum parsimony using PAUP* (portable version 4.0b10) (SWOFFORD 2002) and are available at TreeBase (www.treebase.org). The maximum parsimony analyses were performed with heuristic search options based on simple taxon addition, treebisection-reconnection (TBR) branch swapping algorithm and Multrees options enabled. The maximum likelihood analyses were calculated using Treefinder (Јовв 2008) and using evolutionary models as proposed by the software (ITS1: TN:G:5; ITS2: J2:G:5). To test the confidence of the trees topologies, we calculated bootstrap analyses by distance (NJ; 1000 replicates), MP (1000 replicates) and maximum likelihood (ML; 1000 replicates) criteria. For both datasets, Bayesian analyses were performed using MrBayes version 3.1. (HuelsenBeck \& Ronquist 2001). Two runs with four chains of Markov chain Monte Carlo (MCMC) iterations were performed for 10,000,000 generations and covarion settings with tree sampling every 100 generations. The stationary distribution was assumed when the average standard deviations of split frequencies between two runs were lower than 0.01 and Tracer V1.4 (RAmBAut \& DRUMMOND 2007) was used to check the stationary phase and to identify an appropriate burn in value. The first $25 \%$ of the calculated trees were discarded as burn-in. 50\% majority-rule consensus trees were calculated for posterior probabilities (PP). We used the ITS-2 model of VAN HANNEN et al. (2002) and adapted it by hand.

\section{RESULTS}

The ITS1, ITS2 and 5.8S rRNA gene sequences determined during this study and deposited in GenBank are shown in Table S1; sequences obtained from GenBank and used in the analyses are shown in Table $\mathrm{S} 2$. The $5.8 \mathrm{~S}$ alignment showed zero differences for most of the strains; strain Krienitz 1981-313 of Pectinodesmus pectinatus HEGEWALD et al., Dimorphococcus and Westella differed by one nucleotide from the remaining strains; Coelastrella, Hylodesmus and the strains Mary 9/21 BT-16W and Mary 9/21 BT-19W differed by two nucleotides; Coelastrum astroideum DE NotARIS differed by three nucleotides.

The ITS2 tree (MB/ML/MP/NJ) (Fig.1) displayed several clusters, which largely corresponded to described genera. These clusters had mainly bootstrap values above $50 \%$, while the phylogenetic relationships among these clusters were weakly supported with bootstraps below $50 \%$. The most deeply diverging branches were the morphologically distinct genera Dimorphococcus and Westella. The next, still unsupported branching recognized two main groups, one of which included Pectinodesmus, Verrucodesmus gen. nov., Chodatodesmus gen. nov., Coelastrum, Coelastrella, Enallax, and Comasiella. The second group included the genera Scenedesmus, Acutodesmus, 
Tetradesmus, Desmodesmus and Hylodesmus. This basic pattern was similar in the ITS1 tree (Fig. 2), except that some taxa were missing.

The clade containing Pectinodesmus comprised several subgroups. The first branch, separated Enallax and two hitherto nameless strains (Mary 9/21 BT-16W, NDem 8/18 T-11W), followed by an unsupported branching into Pectinodesmus and a branch with the genera Coelastrum, Coelastrella, Comasiella and two new genera. The first branch of this group contained three strains, including the type strain of Scenedesmus ecornis var. mucronulatus CHODAT, interpreted as the new genus Chodatodesmus. While the type strain and a strain from Peru (Hegewald 1973-25) had good support except for MB, the third strain ("Antarctic") had no support as member of this clade. The Chodatodesmus strains clustered far from Scenedesmus sensu stricto, although morphologically they were not clearly distinct. The new genus Verrucodesmus, hitherto included in Scenedesmus sensu stricto, was an unsupported sister to Coelastrum.

For the genus Pectinodesmus we studied 17 strains from different continents (Table S1), which were grouped in several subclusters in ITS2 phylogeny, and were slightly differently arranged in the ITS1 phylogram. The genus was supported by high bootstrap values in both trees.

Based on the phylogenetic trees and/or morphological differences, the following descriptions or new combinations were necessary.

\section{Chodatodesmus E. Hegewald, C. Bock et Krienitz gen. nov.}

Single celled, cell wall smooth; cells elliptical, about twice as long as wide, up to $10 \mu \mathrm{m}$ long. Characterized by its ITS2 sequences: NCBI GenBank accession numbers JQ240287, JQ082315, AM419228.

Type species: Chodatodesmus mucronulatus (CHODAT) E. Hegewald, C. Bock et Krienitz

Chodatodesmus mucronulatus (CHODAT) E. Hegewald, C. Bock et Krienitz comb. nov.

Basionym: Scenedesmus ecornis var. mucronulatus CHODAT 1926. (Schweiz.) Z. Hydrol. (Revue d'Hydrologie) 3: 170.

Type strain: Chodat 182 (previously collection Geneve, Switzerland; now SAG 2332).

Type ITS2 sequence: GenBank JQ240287.

Representative strain: CCAP 276-41 (= Hegewald 1973-25), from Peru.

Representative ITS2 sequence: GenBank JQ082315.

Verrucodesmus E. Hegewald gen. nov.

Description: Cells ovate to obtuse elongate. Cell length less than $10 \mu \mathrm{m}$. Cells arranged costulate or altermate in $4-8$ celled coenobia, embedded in mucilage. Cell walls granulated by precipitated material.

Type species: Verrucodesmus verrucosus (Y.V. RoLL) E. Hegewald
Verrucodesmus verrucosus (Y.V. RoLl) E. Hegewald comb. nov.

Basionym: Scenedesmus verrucosus Y.V. Roll 1925 Russk. Arkh. Protistol. 4: 145, 150.

Synonym: Scenedesmus bijugatus var. disciformis CHodat.

Verrucodesmus parvus (G.M. SмITH) E. Hegewald comb. nov.

Basionym: Scenedesmus bijuga (var. alternans) f. parvus G.M. SмIтн 1916 Transact. Wisc. Acad. Sci., Art \& Lett.18: 488.

Pectinodesmus holtmannii E. Hegewald, C. Bock et Krienitz spec. nov.

Type: Fig.6.

Type strain: Krienitz 2005-5 (= SAG 2385)

Type locality: Tunisia, Djerba, oxidation pond.

Cells $25-60 \times 5-12 \mu \mathrm{m}$, straight to slightly bent, cell length to cell width 5-8:1. Coenobia with 4-8 linear or slightly alternately arranged cells. Cells under the SEM with longitudinal ridges and on top of the cells many bristles were excreted. ITS1/5.8S/ITS2: NCBI GenBank accession number JQ082334.

Representative strain: Krienitz 2005-7, NCBI GenBank accession number JQ082335.

Etymology: The name was given in honour of the late Theodor Holtmann (1951-2010), a phycologist who wrote a thesis and a paper on Acutodesmus (Scenedesmus subg. Acutodesmus) (Holtmann \& Hegewald 1986, Holtmann 1994).

The new species was hitherto known from the type locality only.

For the following species a lectotype was selected and the species was transferred to Pectinodesmus.

Scenedesmus javanensis CHOdAT 1926: (Schweiz.) Z. Hydrol. (Revue d'Hydrologie) 3: 157-158.

Lectotype: ChODAT 1926, fig. 551, coenobium on the right side.

Pectinodesmus javanensis (СHODAT) E. Hegewald, C. Bock et Krienitz comb. nov.

Basionym: Scenedesmus javanensis CHODAT 1926. (Schweiz.) Z. Hydrol. (Revue d'Hydrologie) 3: 157.

Synonyms: Scenedesmus acuminatus var. javanensis f. globosus Uherkovich in Uherkovich \& RAI 1977, Scenedesmus javanensis f. schroeteri (HuBER-Pestalozzi) Comas et KomÁrex 1984, Scenedesmus obliquus f. magnus Bernard 1908, Scenedesmus schroeteri Huber-Pestalozzi 1936, Acutodesmus javanensis (CHODAT) TSARENKO in Tsarenko \& Petlevanny 2001

Several new combinations were necessary:

Pectinodesmus pectinatus f. tortuosus (SKUJA) E. Hegewald comb. nov.

Basionym: Scenedesmus falcatus f. tortuosus SKUJA 1927: Acta Hort. Bot. Univ. Latv. 2: 83. 


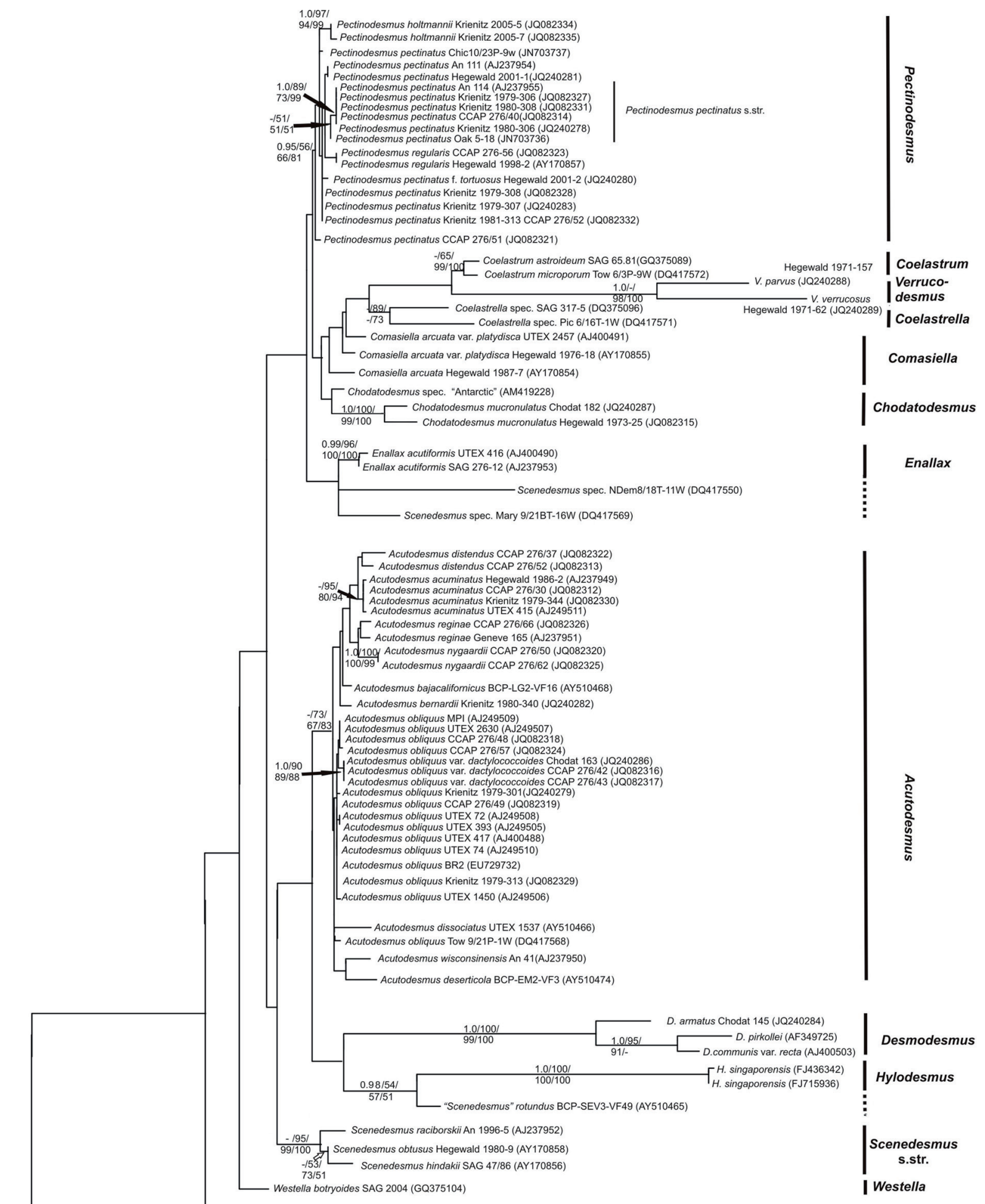

Dimophococcus lunatus SAG 224-1(GQ375103)

I Dimorphococcus

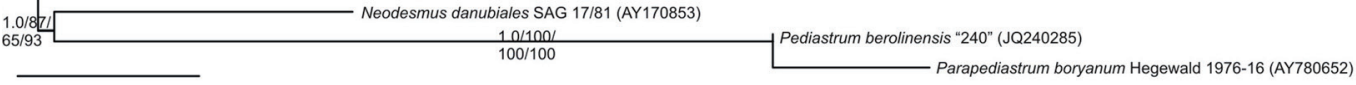

I Neodesmus

Pediastrum

| Parapediastrum

$0.2 \quad \mathrm{MB} / \mathrm{ML}$

Fig. 1. Maximum-likelihood (ML) phylogenetic tree inferred from ITS2 rRNA gene sequences. Support values correspond to Bayesian PP, ML BP, MP BP, NJ BP. Hyphens correspond to values $<50 \%$ for BP and $<0.95$ for PP. Scale represents the expected number of substitutions per site. Strain numbers used as mentioned in Table S1. 


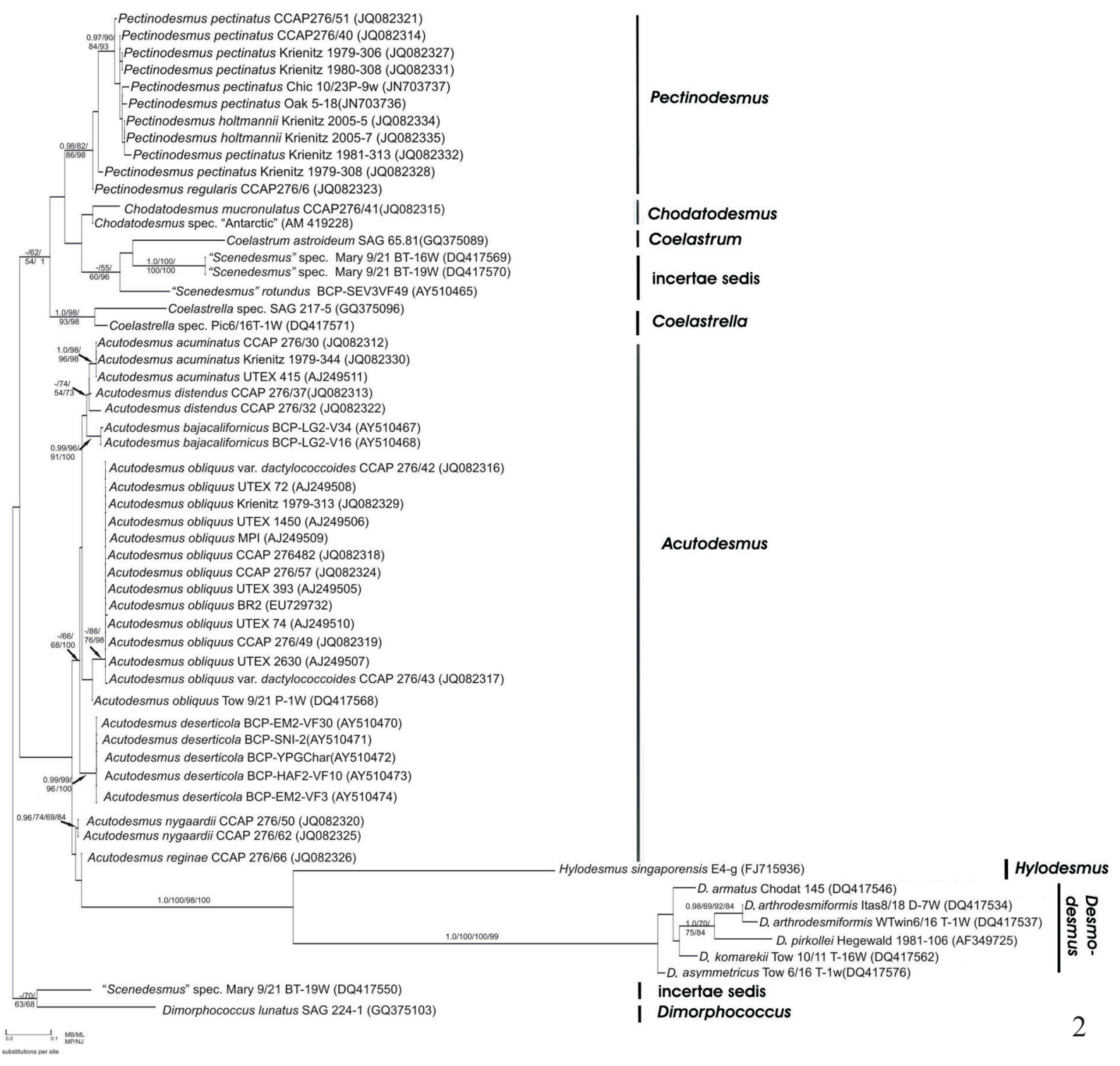

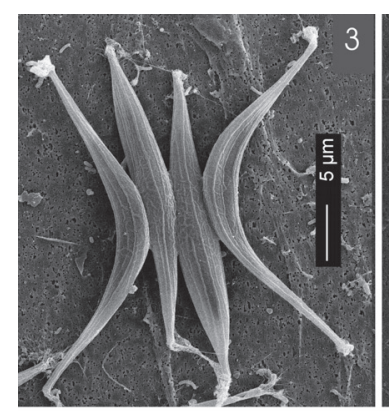
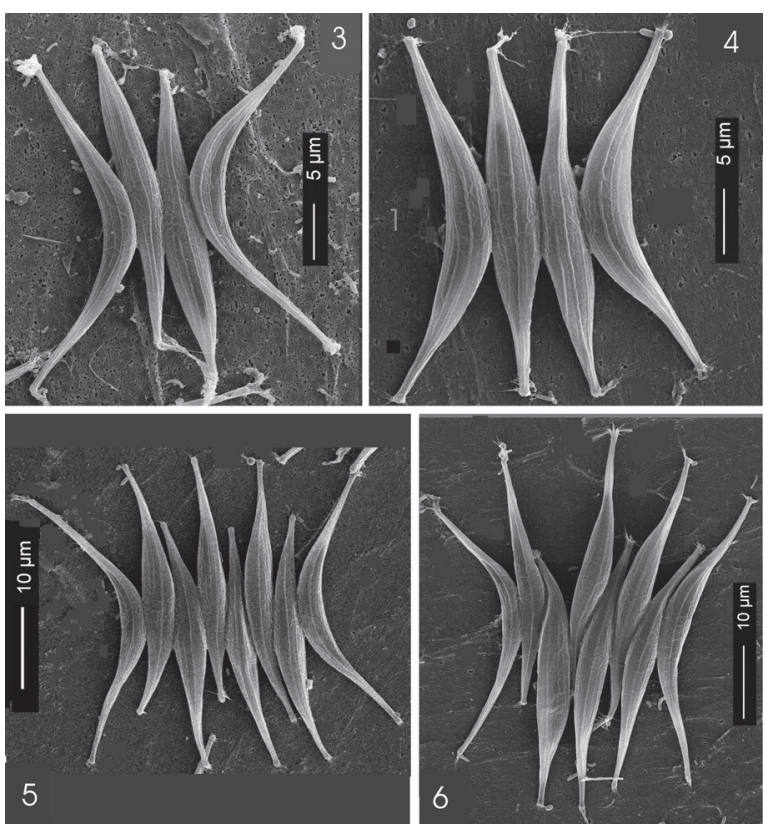

Fig. 2. Maximum-likelihood (ML) phylogenetic tree inferred from ITS1 rRNA gene sequences. Support values correspond to Bayesian PP, ML BP, MP BP, NJ BP. Hyphens correspond to values $<50 \%$ for $\mathrm{BP}$ and $<0.95$ for PP. Branch lengths represent substitutions per site. Strain numbers used as mentioned in Table S1.

Figs 3-6. Variability of Pectinodesmus holtmannii strain Krienitz 2005-5 under the SEM 


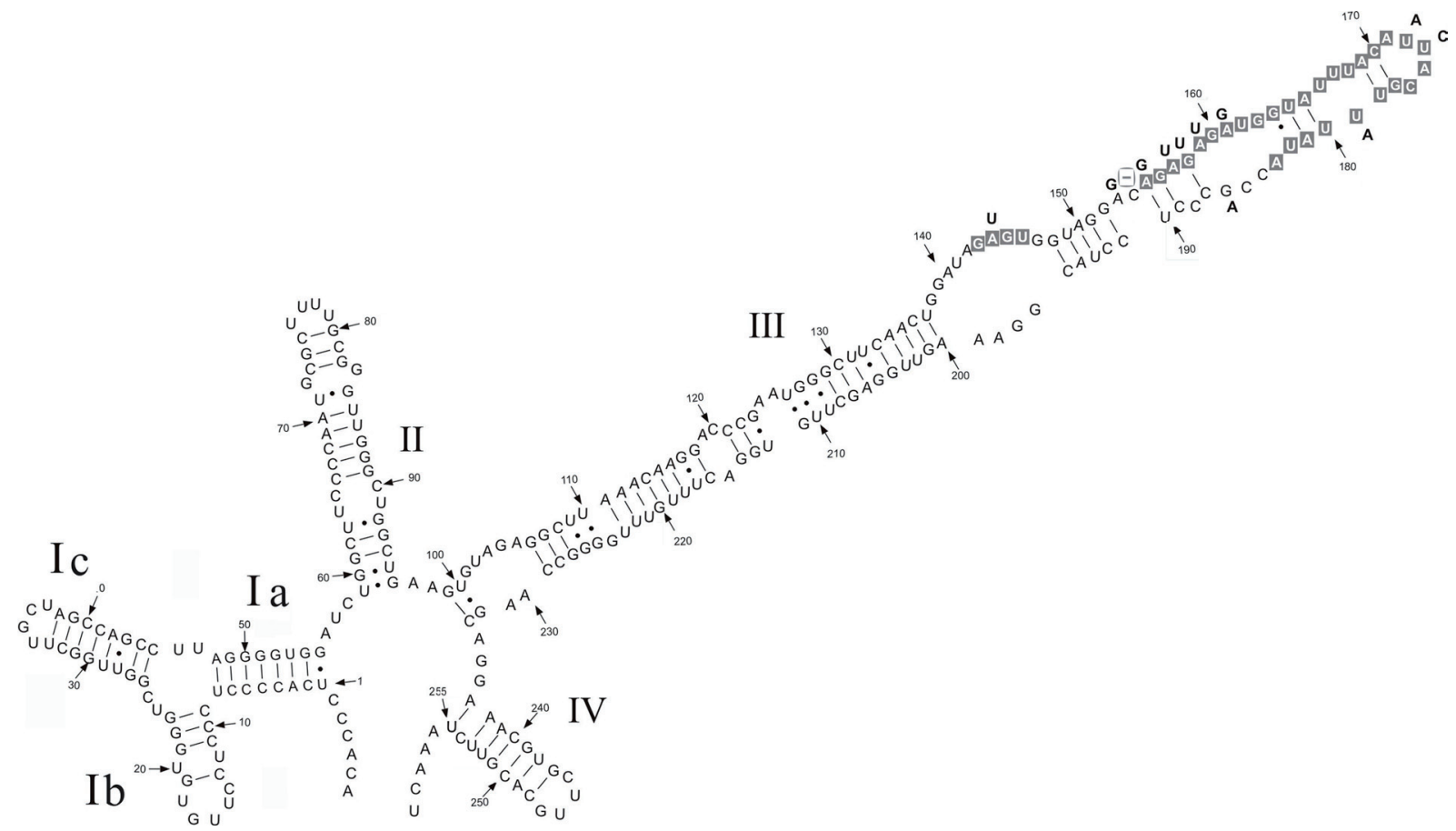

Fig. 7. ITS2 model for the type strain of Chodatodesmus mucronulatus, strain Chodat 182, compared to strain CCAP 276/41. The prolongation of helix III is marked in grey boxes. The differences of strain CCAP 276/41 are shown by bases in position of exchange (all are in the prolongation of helix III).

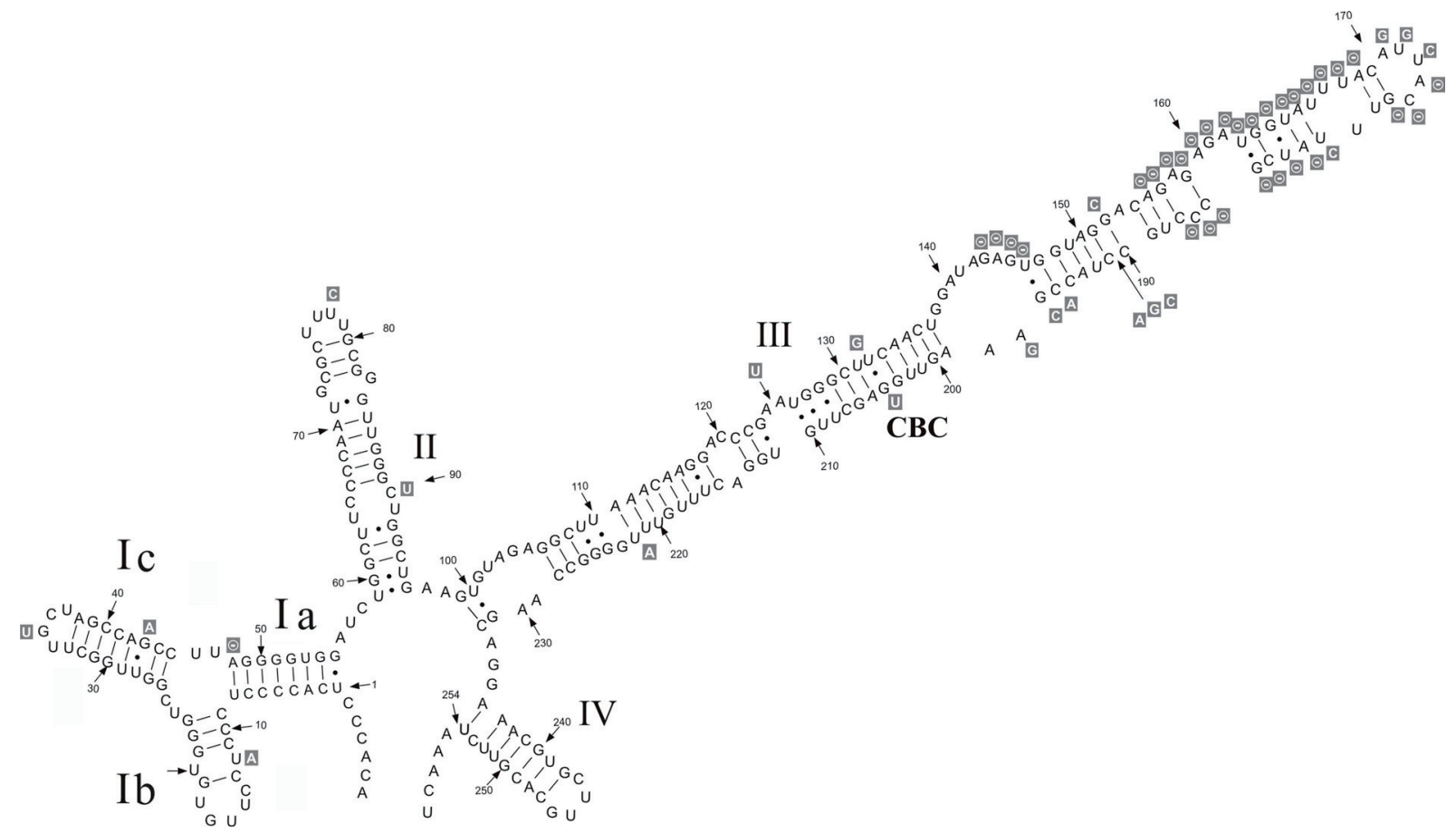

Fig. 8. ITS2 model for Chodatodesmus mucronulatus strain Chodat 182, the differences to strain „Antarctic“ are in grey boxes. 


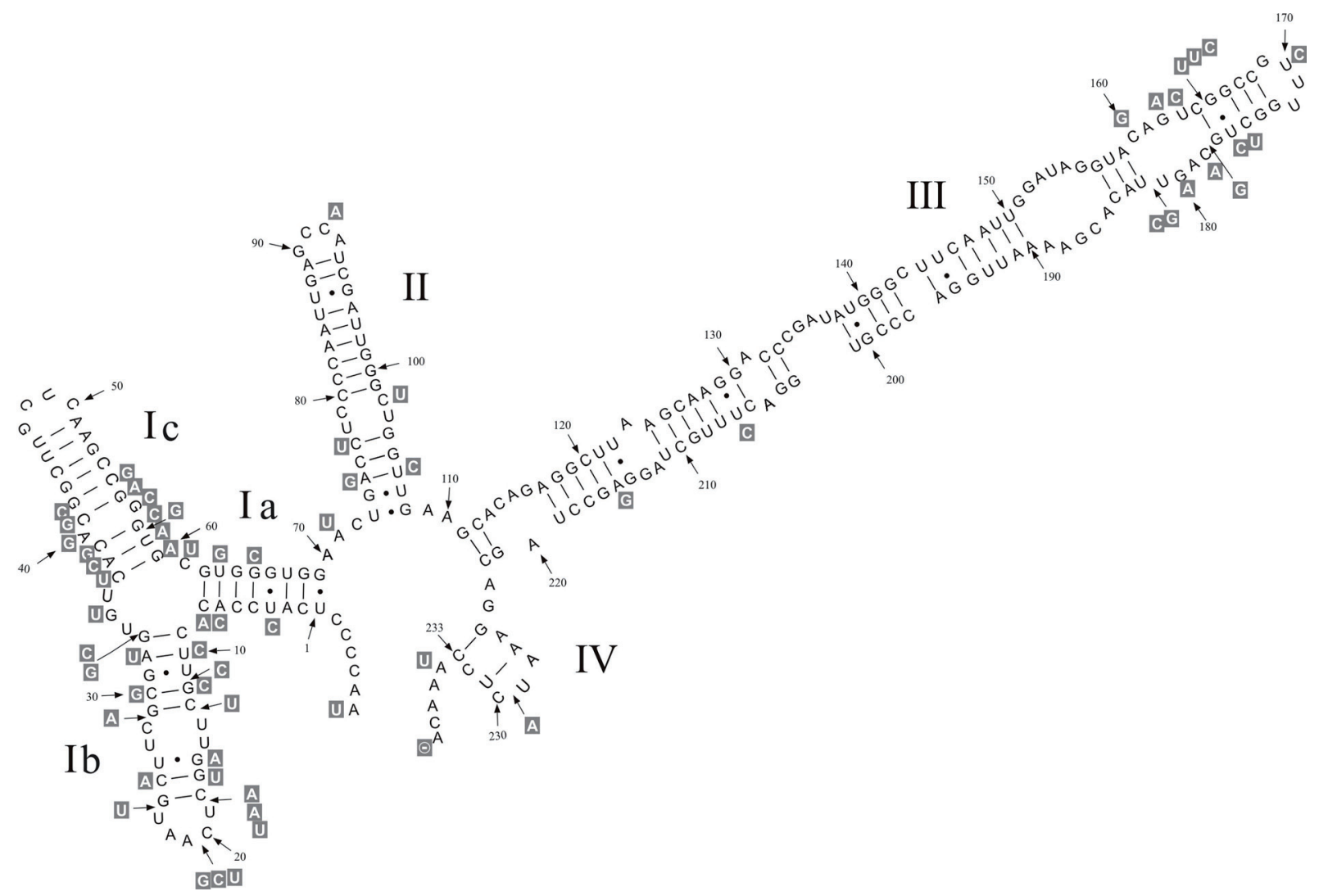

Fig. 9. ITS2 model for Verrucodesmus verrucosus. In gray boxes are the different bases of V. parvus.

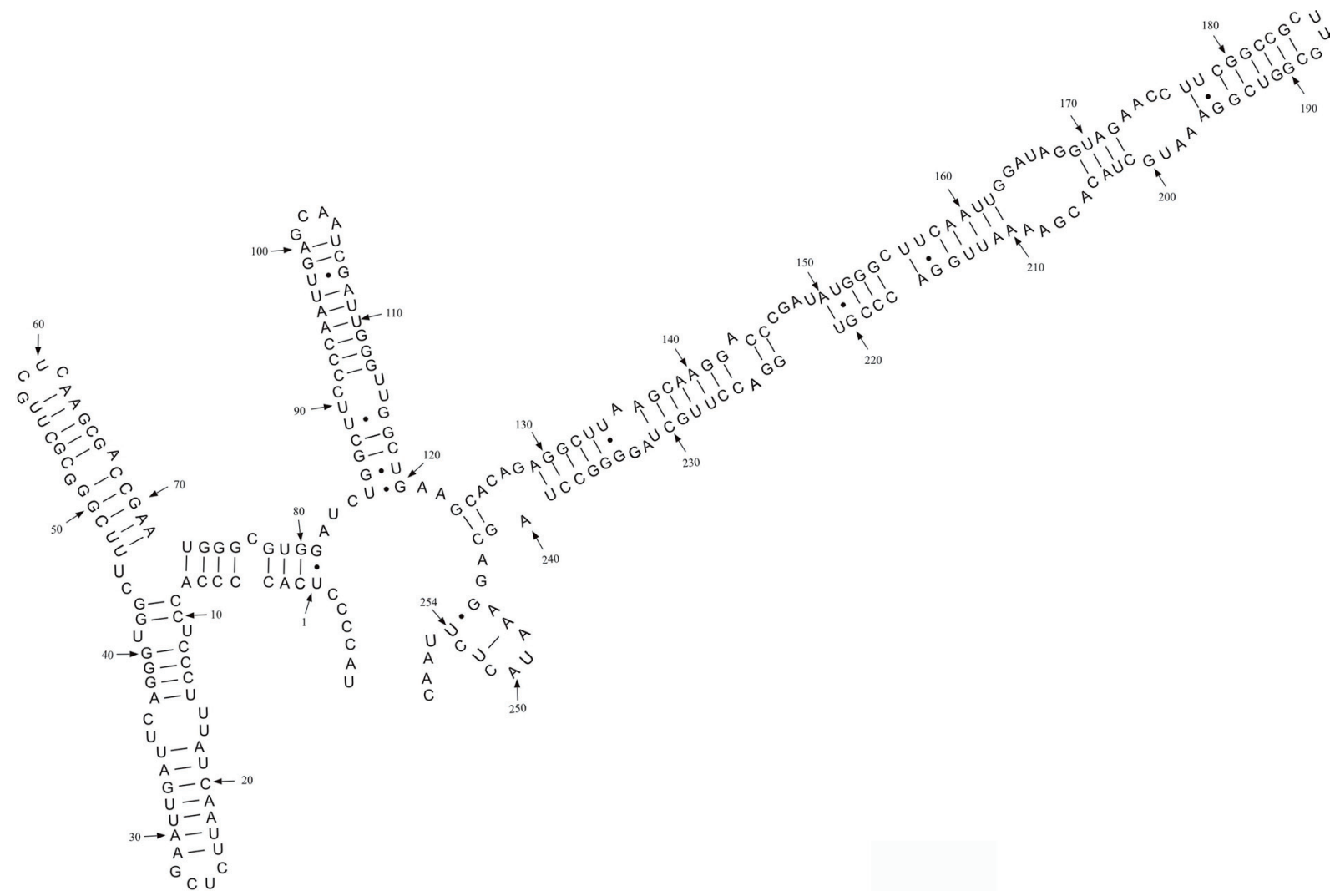

Fig. 10. ITS2 model for Verrucodesmus parvus. 
Acutodesmus distendus (Holtmann) E. Hegewald, C. Bock et Krienitz comb. et stat. nov.

Basionym: Scenedesmus pectinatus var. distendus HoLtMANN 1994 Diss. Uni. Essen, tome 1: 77.

Acutodesmus nygaardii (Huber-Pestalozzi) E. Hegewald, C. Bock et Krienitz comb. nov.

Basionym: Scenedesmus nygaardii Huber-Pestalozzi 1932 Ber. Schweiz. Bot. Ges. 46: 154.

Synonym: Scenedesmus javanensis f. nygaardii (HubERPestalozzi) Comas et Komárek 1984, Scenedesmus obliquus var. nygaardii (Huber-Pestalozzi) Holtmann

Validation: Scenedesmus bajacalifornicus L.A. LEwIS et Flechtner. Lectotype: fig. 1B in Lewis \& Flechtner: Cryptic species of Scenedesmus (Chlorophyta) from desert soil communities of Western North America. J. Phycol. 40, 1127-1137.

Acutodesmus bajacalifornicus (L.A. LewIs et Flechtner) E. Hegewald, C. Bock et Krienitz comb. nov.

Basionym: Scenedesmus bajacalifornicus L.A. LEwIS et FLeChTNER (validation see above).

Acutodesmus bernardii (G.M. Sмітн) E. Hegewald, C. Bock et Krienitz comb. nov. Basionym: Scenedesmus bernardii G.M. SмIтн 1916: Trans. Wisc. Acad. Sci., Arts \& Lett. 18: 436

Synonyms: Scenedesmus pseudobernardii Comas et KomÁreK 1984, Acutodesmus pectinatus var. bernardii (G.M. Smith) Tsarenko in Tsarenko \& Petlevanny 2001.

Further synonyms see Hegewald \& SiLva (1988).

Acutodesmus dissociatus (P.A.Verses et F.R. Trainor) E. Hegewald, C. Bock et Krienitz comb. nov.

Basionym: Dactylococcus dissociatus P.A. Verses et F.R. TrainOR 1966. Phycologia 6: 79-82.

Synonyms: Keratococcus dissociatus (P.A. Verses et F.R. Trainor) H. Ettl et G. Gärtner, Scenedesmus dissociatus (P.A. Verses et F.R. Trainor) E. Hegewald et N. Hanagata

Validation: Scenedesmus deserticola L.A. LEWIS et Flechtner 2004. Lectotype: figs 1D, 2A, 2B in LEWIS \& FLECHTNER: Cryptic species of Scenedesmus (Chlorophyta) from desert soil communities of Western North America. J. Phycol. 40, 1127-1137.

Acutodesmus deserticola (L.A. LEWIS et Flechtner) E. Hegewald, C. Bock et Krienitz comb. nov.

Basionym: Scenedesmus deserticola L.A. LEWIS et FleChtNer 2004. J.. Phycol. 40: 1133-4, validated above.
Acutodesmus obliquus var. dactylococcoides (Chodat) E. Hegewald, C. Bock et Krienitz comb. et stat. nov.

Basionym: Scenedesmus dactylococcoides CHODAT 1926 (Schweiz.) Z. Hydrol. (Revue d'Hydrologie) 3: 132.

\section{Discussion}

The common problem in the systematics of Scenedesmaceae was a low bootstrap support for the basis of the trees and a good support only of smaller groups of species or genera (ELIÁš et al. 2010; HEGEWALD et al. 2010). However, these clusters are in accordance in the ITS1 and ITS2 tree and also similar in the 18S tree of ELIÁš et al. (2010), supporting the probability of the phylogenetic information of the branches despite their low bootstrap values.

A sister branch to Comasiella, Coelastrella, Coelastrum and Verrucodesmus was the new genus Chodatodesmus. With its straight to slightly curved cells it was morphologically not clearly distinct from Scenedesmus sensu stricto. For two strains, an insertion was found in the ITS2-model in helix III. The strain CCAP 276/41 differed from the type strain in 16 bases (Fig. 7), but except two, all base exchanges were in the insertion of helix III. The third strain of this group, Scenedesmus spec. „Antarctic”, clustered with the two strains of Chodatodesmus mucronulatus but it had no insertion in helix III and additionally it had one CBC (G-U/U-G) and about 10 base changes beside the lack of the insertion of helix III (Fig. 8). It coincided with one strain of $C$. mucronulatus in the alignment of ITS1 and 5.8S (not sequenced for the type strain), therefore it was included in the new genus Chodatodesmus. The strain Scenedesmus spec. „Antarctic” represents a species and it was intended to become described (see: GenBank AM419228). However, it was not done until today and we did not describe it here. The description of the type taxon (Scenedesmus ecornis var mucronulatus) in CHODAT (1926) was very poor. The mentioned spines (mucronultae), distinguishing it from other taxa of Scenedesmus ecornis (EHRENB. ex RALFS) Chodat, were not visible in our cultures.

A well supported sister clade to the supported branch of Coelastrum contained two strains of the newly erected genus Verrucodesmus, hitherto treated as Scenedesmus taxa (Fig. 1). Beside their position in the tree far from Scenedesmus sensu stricto they also differ by more than hundred base exchanges (Table S3) and morphologically by a granulation of the cell wall. This granulation is not a cell wall structure but excreted material, in the Scenedesmaceae only known for Verrucodesmus. The two species of the genus differed from all other taxa studied here especially by a prolongation of helix I b, c and by an additional mini-loop of four bases of $\mathrm{C}$ and $\mathrm{U}$ in helix $\mathrm{Ib}$ (Fig. 
9), which was otherwise found in all Scenedesmacae only at the bases of helix II. Remarkable was a strongly reduced helix IV, which was hitherto known only for Neodesmus, Hylodesmus and for Desmodesmus denticulatus (Lagerheim) S.S. An, E. Hegewald et FrIEDL. These were no close relatives to each other or to Verrucodesmus. The latter genus differed from the next branching genera Coelastrum, Coelastrella and Comasiella, as also from Scenedesmus by 107 to 134 bases (Table S3), but the two species of Verrucodesmus also differed from each other by the high number of 76 base exchanges and at least $7 \mathrm{CBC}^{\prime}$ s. ITS2 contained in $V$. parvus 254 bases, in $V$. verrucosus 233. The additional bases of $V$. parvus were especially used for the prolongation of helix Ib, the basis of helix Ic was changed totally, most other changes were in the tip of helix III. Although there were many and severe differences between the two species, we kept them in the newly erected genus Verrucodesmus, because both were similar in their general ITS2 structure (Figs 9, 10). Because the cell wall granulation was not always visible under the light microscope, we included Scenedesmus bijugatus var. disciformis as synonym.

The Pectinodesmus cluster (ITS2) was composed of 18 strains of three species which had only up to 11 base exchanges, and differing from the genus Acutodesmus by more than 30 and by over 50 exchanges from Chodatodesmus mucronulatus. In 5.8S there were no differences between the strains. One subcluster contained five strains from Germany and Korea, which had 0-1 bases differences compared to each other. Attached to this cluster was a strain from USA, which differed from this cluster by 2-3 bases (Oak 5-18). From the other strains of Pectinodesmus they differed by 5-8 bases and they also differed by one CBC in the tip of helix II (except strain Oak 5-18 which had a semiCBC in that position, Fig. 11). The branch was supported by bootstrap values over 50 . We treated this group as $P$. pectinatus sensu stricto. The typical cells and cell arrangement of the group were shown for strain Oak 5-18 (Fig. 12).

The first branch of the Pectinodesmus cluster in ITS2 contained a single strain: CCAP 276-51 from Finland (Fig. 1). This strain had also an isolated position in the ITS1 tree (Fig. 2). Because it was morphologically identical to the type, we treated it preliminarily as Pectinodesmus pectinatus sensu lato. Several further branches with strains hitherto labelled S. falcatus Chodat, S. acutus Meyen and S. acutus $\mathrm{f}$. costulatus (CHODAT) UHERKOVICH were also treated as P. pectinatus sensu lato until further data are available.

One strain (Hegewald 2001-02) had coenobia with twisted cells (Figs 13-14). Another strain isolated from the same pond had the cells in one plane (strain Hegewald 2001-1) and was in a separate but unsupported branch together with a strain from Korea (An 111). Between these two morphologically different strains were only three base differences in loops and one in the connecting part to $5.8 \mathrm{~S}$. Because of the morphological difference we treated strain Hegewald 2001-2 (fig. 19 in Hegewald et al. 2010) as a forma.

A unsupported branch with two strains which were characterized by a special cell shape, represented $P$. regularis (Svirenko) E. Hegewald \& others. This species differed by $5-11$ bases from other Pectinodesmus species and strains (Table S4). Although the low number of base exchanges and the lack of a CBC the $P$. regularis it was accepted as a species because of its morphology (HEGEwALD et al. 2001) and differences in chromosome number (Dzhambazov et al. 2001). However, Dzhambazov et al. (2006) noticed a strain ( $P$. pectinatus f. regularis Mladenov) with four and five chromosomes, which was discussed as intermediate between $P$. pectinatus and $P$. regularis.

Dzhambazov et al. (2001, 2002 a, b, 2003, 2006) studied thekaryotype ofdifferentspecies of Acutodesmus and Pectinodesmus and found chromosome numbers between 4 and 6. For Acutodesmus obliquus (TURPIN) Tsarenko in Tsarenko \& Petlevanny, A. bernardii and Pectinodesmus regularis they counted four, for Acutodesmus acuminatus, Scenedesmus obtusiusculus and Pectinodesmus pectinatus five and for P.javanensis (sub nom. Acutodesmus nygaardii) and „Scenedesmus antennatus Brébisson" six chromosomes. Although the identification of some species is not validated, at least $A$. obliquus and $A$. acuminatus which are weakly separated in our ITS2 tree (Fig. 1) as also A. obliquus and ,Scenedesmus obtusiusculus “ and Pectinodesmus pectinatus and $P$. regularis differ in the chromosome numbers. The chromosome number seems to be variable in both genera.

One branch with high bootstrap values contained two strains which were special by their morphology and differed from all other Pectinodesmus strains by 7-11 base exchanges and one CBC (Fig. 11). They were described as a new species: P. holtmannii. In morphology the $P$. holtmannii had some similarities with Scenedesmus javanensis CHODAT. Because the figures of the type description of $S$. javanensis were very different (CHODAT 1926) we proposed a lectotypification. The species was reported in literature several times, mainly from tropical areas from different continents: Indonesia (CHODAT 1926, type locality, BERNARD 1908 sub nom. Scenedesmus obliquus f. magnus p.p., Huber-Pestalozzi 1936 sub nom. S. schroeteri), Ivory Coast (UhERKOvich \& RAI 1977 sub nom. S. acuminatus var. javanensis f. globosus), Brazil (Silva 1999; Rodrigues et al. 2010 sub nom. S. bernardii), Amazon lowlands of Colombia (ECHENIQUE et al. 2004 sub nom. S. javanensis f. schroeteri, India (Hegewald et al. 1990) Taiwan (Yamagishi 1992) and Japan (Ooshima 1981; Protist Information Server 19952010; YAmAgishi \& Hegewald in YAMAGishi \& Akiyama 1995). Because no cultured strain was available the species could not be sequenced. According to the long and narrow cells $(20-50 \times 2-8 \mu \mathrm{m})$ we transferred it to 


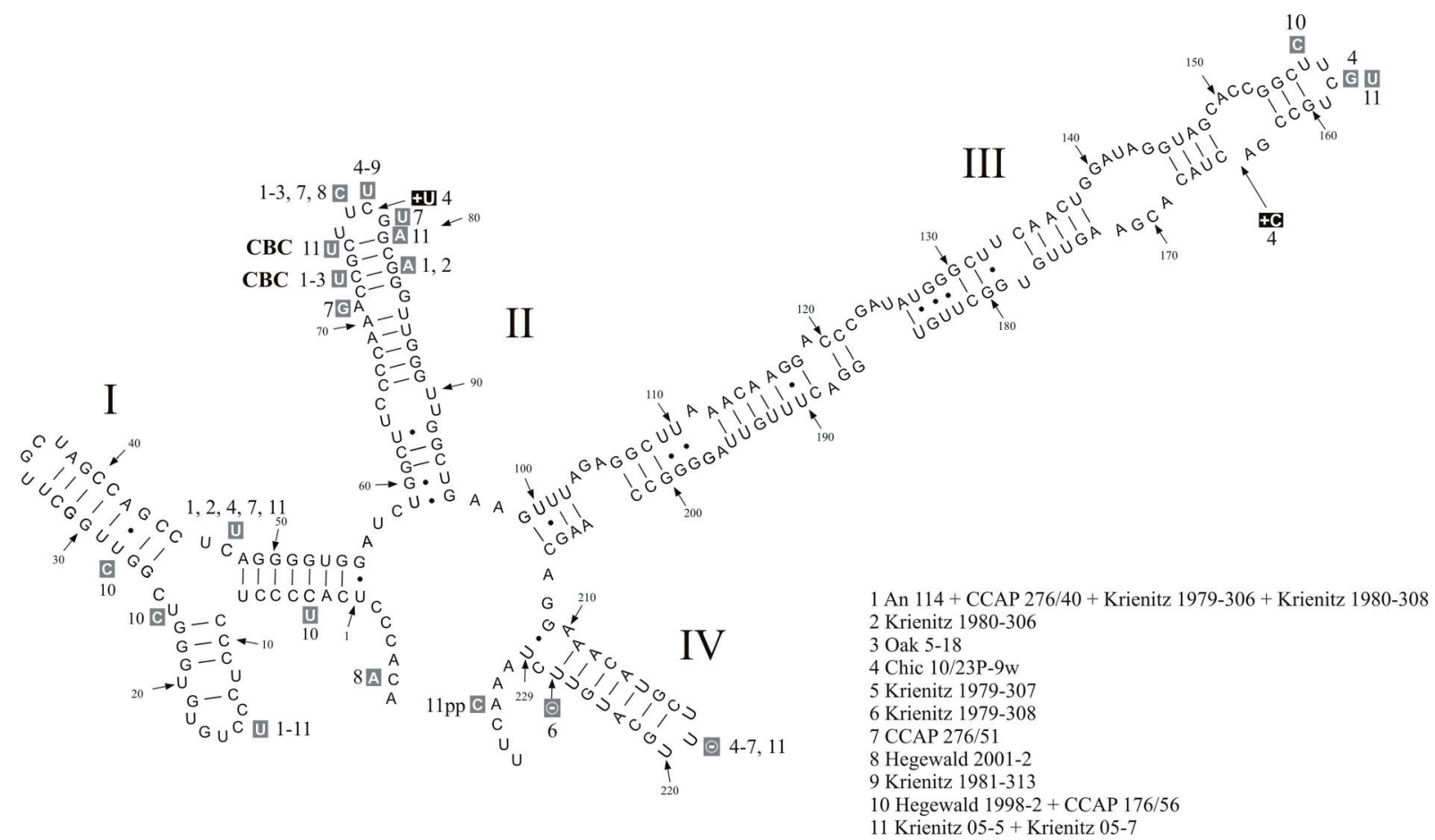

Fig. 11. ITS2 model for Pectinodesmus pectinatus (strains Hegewald 2001-1 and An 111) and the base exchanges of the other studied Pectinodesmus strains or species.

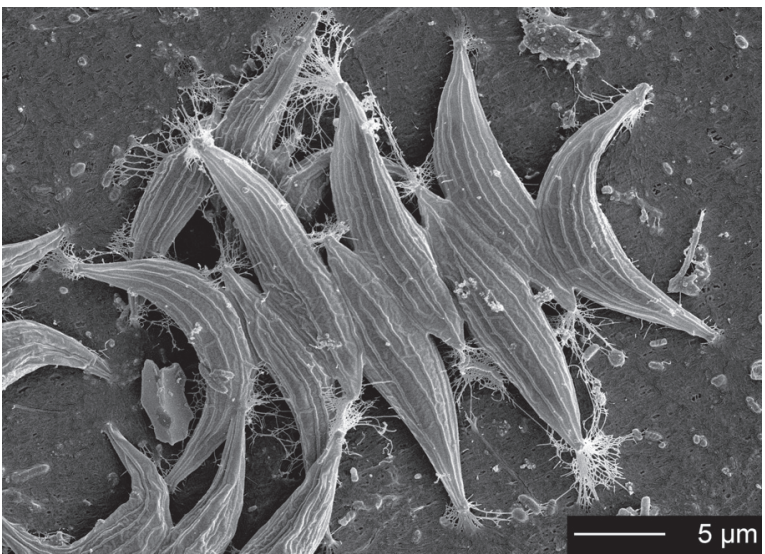

Fig. 12. Pectinodesmus pectinatus, a typical coenobium of strain Oak $5-18$ with the cells arranged in a plane. A heavy bristle production was visible at all cell poles.

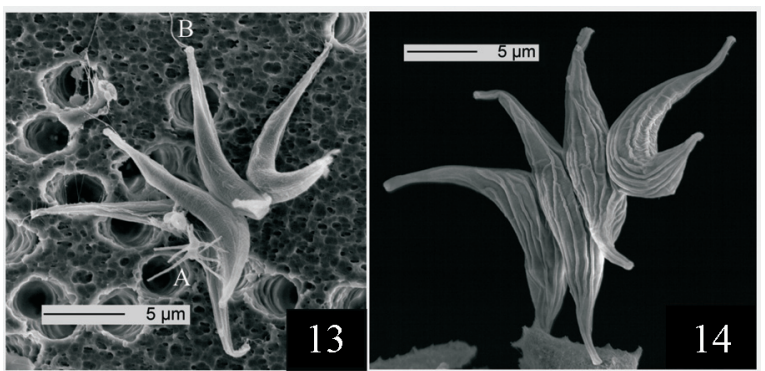

Figs 13-14. Pectinodesmus pectinatus f. tortuosus under the SEM: (13) specimen from Lake Fauler See, Berlin; a bacterium Ancalomicrobium adetum, b bristels; (14) strain Hegewald 2001-2, isolated from Lake Fauler See.
Pectinodesmus. The morphological somewhat similar Scenedesmus bernardii differed in smaller size and less elongated cells and by some cells touching with their cell poles.

The genera Pectinodesmus and Acutodesmus were in separate clusters in the ITS1 and ITS2 trees and had more than 30 bases difference and five $\mathrm{CBC}^{\prime} \mathrm{s}$ in ITS2. The cluster including Acutodesmus had branches with Scenedesmus, Desmodesmus and Hylodesmus. The Acutodesmus cluster itself had bootstrap values between 67 and 83 . The genus had several subclusters, but only three had bootstraps values over 50 . Two of the taxa/strains of Acutodesmus had one CBC. The base changes in Acutodesmus strains were shown in Fig. 15.

One of the supported subbranches represented Acutodesmus acuminatus (LAGERHEIM) TSARENKO in Tsarenko \& Petlevanny. The species was morphologically well characterized by its elongated strongly curved cells arranged in a curved coenobial plane and by traces of mucilage in the center of the coenobia (e.g. figs 5, 6 in AN et al. 1999). The strains of this species differed by $2-5$ and from $A$. obliquus by 10-14 bases but no CBC was detected.

The strain Holtmann 1977-5903 (= CCAP 276/37) from Germany was identified by HoLTMANN (1994) as Scenedesmus pectinatus var. distendus and a second strain from New Zealand as Scenedesmus obliquus var. nygaardii. They formed an unsupported sister clade to A. acuminatus in the ITS2 tree and clustered as separate lineages in the ITS1 phylogeny. 


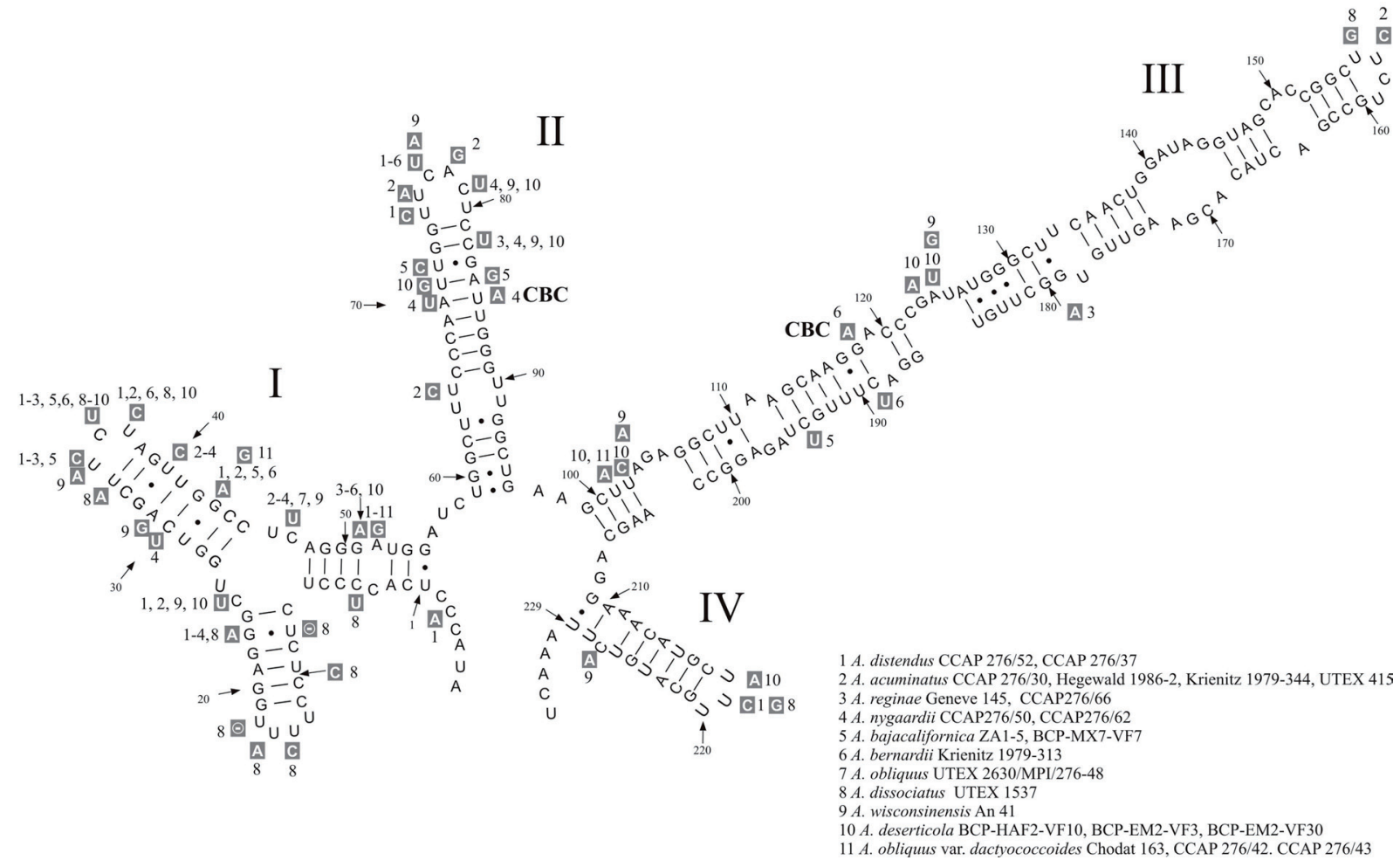

Fig. 15. ITS2 model for Acutodesmus obliquus (strain UTEX 72) and the base exchanges of other studied Acutodesmus strains or species.

Both strains differed from each other by 16 base exchanges and from Acutodesmus obliquus by 17-21 base exchanges but had no CBC. Because there were no notable morphological differences between both strains (compare HolTMAnN 1994, pl. 13, 16) we treated them both as $A$. distendus. The species level was recommended according to their placement in the phylogenetic trees (Figs 1, 2).

A sistergroup to Acutodesmus acuminatus and A. distendus included A. nygaardii and two strains hitherto labelled Tetradesmus. As Acutodesmus nygaardii we analysed two strains from Bali, Indonesia. These were also studied by Holtmann (1994) but labelled differently, the strain Hegewald 1981-100 (now CCAP 276/50) was identified as Scenedesmus obliquus var. nygaardii (Huber-PestalozzI) HoltmanN and strain Hegewald 1981-86 (now CCAP 276/62) as Pectinodesmus pectinatus. Comparing the morphology of the two strains, we did not find differences (see Holtmann 1994, pl. 5). According to Holtmann (1994) the A. nygaardii was known from Germany, Hungary and Indonesia. Because of its position in the phylogenetic trees (Figs 1,2) we treated them as a species.

Before the cluster Acutodesmus distendus/A. acuminatus/A. reginae/A. nyygaardii branched Scenedesmus bernardii and S. bajacalifornicus. We transferred both species to Acutodesmus. The A, bajacalifornicus differed by 12 bases from $A$. obliquus (strain UTEX 72) and had no CBC. The species as also A. deserticola were invalidly described although strains were given as types. However the strains were cited as e.g. for Scenedesmus deserticola as "Biotic crust project BCP-SEV3-VF49, UTEX strain collection". The project number is identical with a strain number in table 2 of Lewis \& Flechtner (2004) but strains of all three described taxa are not in the strain collection UTEX (http://web.biosci.utexas.edu/utex/). We validated the taxa and transferred Scenedesmus bajacalifornicus and S. deserticola to Acutodesmus.

The strain originally labelled Scenedesmus pseudobernardii f. globosus (Hortobagyi) KrIENITZ (strain Krienitz 1980-340) built a sistergroup to Acutodesmus bajacalifornicus. Its morphology was striking (KRIENITZ 1987: fig. 16 b, c). The ITS2 sequence differed by 11 bases from $A$. obliquus (UTEX 72) and it had one CBC in a conserved part of helix III. This was a strong argument to keep Scenedesmus pseudobernardii on species level, but we transferred it to Acutodesmus. The correct name for the taxon was Scenedesmus bernardii according to Hegewald \& Silva (1988). Whether the separation of a forma globosus was justified cannot be concluded from our ITS data, because a strain of the typical forma was not available. The strain Krienitz 1979-313, originally labelled $S$, pseudobernardii, was apparently lost. When studied by HoLTMANN (1994) this strain was already, according to its morphology, identified as $S$. obliquus. Our ITS2 data verified this result.

A unicellular strain originally described as Dactylococcus dissociatus later transferred to Scenedesmus and to Keratococcus, was located in an 
own branch. It was embedded in the Acutodesmus cluster and differed by 16 base exchanges from $A$. obliquus (strain UTEX 72). It had no CBC and only three semiCBC's. Also in the $18 \mathrm{~S}$ tree of HegEwald \& Hanagata (2000) it was embedded in Acutodesmus. The production of single cells and the polar excretions resulting in polar attachment of the spindle like cells was weighted heavily, hence the species was first placed in the genus Dactylococcus. The cell arrangement, so-called Dactylococcus-stage, was observed several times in different Acutodesmus strains (e.g. CHODAT 1926).

A branch of the Acutodesmus group included $A$. wisconsinensis and $A$. deserticola. The A. deserticola differed by 16 bases from $A$. obliquus (strain UTEX 72) and had one CBC. Additionally it differed in the ITS1 sequence, where it had 18 base exchanges to $A$. obliquus. The $A$. deserticola and the $A$. dissociatus were morphologically similar in cell shape and size and especially by the excretion of thread-like structures (bristles?) at the cell poles. Between both species were 21-26 base exchanges and in the ITS2 tree they are in different branches, hence they were no close relatives.

The cluster, richest in strains, was Acutodesmus obliquus with 17 strains. Embedded was a bootstrap supported subbranch with three strains from Switzerland and Peru, including the type strain of Scenedesmus dactylococcoides. The subgroup differed from Acutodesmus obliquus by only 2-3 base exchanges. Because of the low differences in base exchanges to $A$. obliquus and the lack of CBC's we treated it as a variety only. In morphology it was difficult to distinguish the taxon from $A$. obliquus, it was small (less than $10 \mu \mathrm{m}$ ) with straight cells, arranged linearly or single cells or cells were attached at cell poles (Dactylococcus-stages, see Chodat 1926: figs 10, 22-24). The 14 strains of Acutodesmus obliquus var. obliquus differed in 0-2 base exchanges (Table S5). Different names were used for the strains: Scenedesmus acutus Meyen, S. obliquus, S. dimorphus (Turpin) KützING, S. naegelii BréBISSON, S. obtusiusculus Chodat, S. pseudobernardii and $S$. spec.

Chodat (1913, 1926), Ahlstrom (1934), Kiriakov (1976), Hegewald (1982, 1989), KrienitZ (1987), Hindák (1990) and Holtmann (1994) studied many strains of the genus Acutodesmus under the light microscope and pointed to a high variability of the taxa. The nine species of the A. obliquus complex described by CHODAT $(1913,1926)$ are not or hardly distinguishable. However, the type strains of Scenedesmus dactylococcoides and S. mucronulatus were supported as species in our phylogenetic analyses. Three of CHODAT 's strains are mainly unicellular: Scenedesmus alpinus CHODAT, S. basiliensis CHODAT and $S$. obtusiusculus, but the type strains were lost. A strain labelled as $S$. basiliensis (UTEX 79) was available; however, this strain was not distinct from the coenobia producing Acutodesmus obliquus strains
(Tables S2, S5). The unicellular strains are usually small celled and if 8-celled coenobia are produced, these had alternating cells (HeGEwald 1982), while A. obliquus had an oblique-costulate cell arrangement (TURPIN 1828). KRIENITZ (1987) could additionally separate Scenedesmus obtusiusculus by its high temperature tolerance $\left(35^{\circ} \mathrm{C}\right)$. However, the $S$. obtusiusculus strain Krienitz 1979-301 was identified by HoLTMANN (1994) as S. obliquus var. inordinatus (KÜTZING) HoLtMANN. According to ITS1/5.8S/ITS2 it was embedded in the Acutodesmus obliquus complex, as also other strains of the group of mainly unicellular strains, as e.g. SAG 276-1 or UTEX 74 (KitschKe 2001).

Acutodesmus obliquus strains with linearly arranged cells and curved outer cells were labelled Scenedesmus dimorphus (e.g. UTEX 417, 1237) and hence were morphologically different from strains labelled Acutodesmus/Scenedesmus obliquus/obtusiusculus. However, they do not show differences in ITS2 sequences. Strains labelled Scenedesmus acutus f. alternans HoRTOBAGYI. (e.g. UTEX $72=$ SAG 276-3a) were misidentified. According to the type description of $S$. acutus f. alternans they should have cell sizes of 24-37.5 $\times$ 8.2-12 $\mu \mathrm{m}$. The cell size of Acutodesmus obliquus (synonym: Scenedesmus acutus) is 4.1-18.1

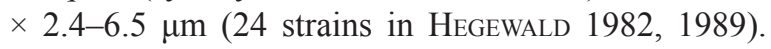
Therefore $S$. acutus f. alternans has the cell size as also cell shape and cell arrangement of Pectinodesmus pectinatus and is a synonym of that species.

Acutodesmus taxa with cells arranged in coenobia in bundles and not in a plane, where treated as a separate genus Tetradesmus (SмITH 1913), but strains with that cell arrangement were in our ITS2 tree in different branches within Acutodesmus, as already shown by KITSCHKE (2001). Strains of Tetradesmus were found in the phylogenetic tree far from each other, while two strains were a sister to Acutodesmus nygaardii, one strain was a sister to $A$. deserticola. The two groups of Tetradesmus differed in cell arrangement. In one group the cells in four-celled coenobia were arranged two to two in two levels (alternatingly as e.g. in Dicloster JAO, WEI et Hu). In the other group the cells were linearly in a bundle, as described for the genus by Sмітн (1913). But all three strains were embedded in Acutodesmus and it was not possible to treat them as an own genus. Tetradesmus wisconsinensis was transferred to Acutodesmus as A. wisconsinensis (G.M. SмIтH) P.M. Tsarenko in Tsarenko \& Petlevanny (2001) and Tetradesmus wisconsinensis var. reginae HoltMAnN to Acutodesmus as A. reginae (Holtmann) P.M. Tsarenko et E. Hegewald in P. Tsarenko, E. Hegewald \& A. BRABAND. We accepted both combinations.

Although the discussed strains of $A$. obliquus showed differences in morphology, which would allow separating taxa, the morphological characteristics are overlapping; hence it is not possible to make clear limits. Additional the ITS1/5.8S/ITS2 data did not allow separation of taxa, despite $A$. nygaardii, $A$. 
distendus and A. obliquus var. dactylococcoides.

The last five (four to six) bases at the end of ITS2 were in unpaired strands (Figs 7- 11, 15) and hence should be variable. However, they built helices with other DNA parts (KELLER et al. 2009). For nearly all here studied genera of the Scenedesmaceae, except Desmodesmus, these bases are AAACU (Acutodesmus, Scenedesmus, Coelastrum - except C. cambricum Archer and C. morum W. et G.S.West - Hariotina, Coelastrella, Dimorphococcus, Pectinodesmus, Comasiella, Enallax, Verrucodesmus, Chodatodesmus, Asterarcys, Westella and Scenedesmus rotundus L.A. Lewis et Flechtner. Different were only Neodesmus (AAACC) and Coelastrella vacuolata (SHIHIRA et R.W. Krauss) E. Hegewald et N. Hanagata (AAACA). In the genus Desmodesmus the base composition is different and variable in composition between species (some also include G) as also in number (four to six).

It raises the question, whether we are forced to distinguish only one genus except Desmodesmus. In our opinion this lumping makes no sense, because there are severe differences in morphology and additionally in coenobial types as e.g. sphaerical coenobia in Coelastrum, flat coenobia in several genera or radial coenobia in Dimorphococcus. The cell walls are smooth in several genera or with longitudinal ridges (Acutodesmus, Pectinodesmus and Enallax), net-like ridges (Coelastrella) or with wart-like structures as in Verrucodesmus. Although we do not know the detailed phylogeny of the group because of the low bootstrap support of the tree at its base, the studied taxa build clear groups, and we treated these as genera.

Is genetic exchange in Scenedesmaceae possible? The Scenedesmacae are known to multiply usually vegetatively, hence each base exchange was given to the next generation. However, TRAINOR (1963) and Trainor \& Burg (1965) observed zoospores in Acutodesmus (Scenedesmus) obliquus. Otherwise zoosporeswere rarely reported. TRAINOR(1996)observed also fusion of zoospores, zygotes and germination of zygotes, hence the zoospores were gametes. The first author and the late A. SCHMIDT observed zoospores in a culture of Desmodesmus insignis (W. et G.S. WEST) E. Hegewald. The dense culture of the strain was forgotten to conserve and was stored for about a week or more in the laboratory. The algae settled and were additionally covered by a layer of the more slowly settling empty cell walls. When controlling the culture under the light microscope plenty of zoospores were observed. The stressful conditions apparently induced the zoospore production. Zoospore production under stressful conditions was also reported by CORRADI et al. (1995a, b) for heavy metals and by TRAINOR \& BURG (1965) for nitrate deficiency. In outdoor mass cultures with its suboptimal conditions zoospore production were reported by СерÁK (1993). The life conditions in our forgotten culture were actually not unpleasant for the algae. Many of the Scenedesmaceae are able to grow heterotrophically (unpublished) and in the dense algal sediment organic substances should be available, released e.g. from dying cells. And under this condition zoospore production was induced. In nature the Scenedesmaceae are especially found in eutrophic ponds and here we always have a sediment layer including plenty of settled algae. If this condition induces zoospore production we should suspect that zoospore production, although rarely observed in well growing cultures, is probably not as rare in nature. Hence genetic exchange between different populations of Scenedesmacae has to be taken into account. For providing evidence for genetic exchange we need more studies of many strains from one locality, as e.g. done by JoHnSON et al. (2007).

Finally the main question is as always the distinguishing of taxa. How many base exchanges are allowed for ITS1/5.8S/ITS2? Beside the possibility that single base identifications may be wrong, we have to accept that a taxon has several base exchanges. A base exchange in $5.8 \mathrm{~S}$ is rare, in ITS2 common and in ITS1 even more common. But the number may not be important as we showed for Chodatodesmus. Severe differences were also between the species Verrucodesmus verrucosus and $V$. parvus (73 base exchanges). Otherwise the base exchanges in a species or between species can be much less, e.g. in Acutodesmus acuminatus one to five, A. deserticola two to eight, $A$. obliquus sensu stricto zero to three (Table S5). However, in A. obliquus we distinguished a var. dactylococcoides (zero base exchanges between the three strains) which differ from the strains of var. obliquus by only 2-3 exchanges, but its cluster had high bootstrap values. Hence it might be not the number of exchanges, but the type (e.g. CBC's) or the position of exchanges (helix or loop, variable or conserved regions) (see Figs 7-11, 15). Although we treated the ITS1/5.8S/ITS2 as an important characteristic we did not neglect morphological characteristics and weighted individually different characteristics (morphology or genetic data) for taxonomical decisions.

ACKNOWLEDGement

We thank the CCAP for strains, O. REYMOND for the CHODAT strains and the Research Center Jülich for use of the SEM. We also thank Mrs. A. BRABAND for 12 DNA analyses. We thank Marvin and Karen FAWLEY for permission to use an SEM photograph (Fig. 12) of their strain Oak 5-18.

\section{REFERENCES}

Ahlstrom, E. H. (1934): The algal genus Scenedesmus. Thesis, Ohio State University. 91 pp.

An, S.S.; Friedl T. \& Hegewald E. (1999): Phylogenetic relationships of Scenedesmus and Scenedesmus-like coccoid green algae as inferred from ITS-2 rDNA sequence comparisons. - Plant Biology 1: 418-428. 
Bernard, C. (1908): Protococcacées et desmidiées d'eau douce, récoltées à Java et décrites par Ch. BERNARD. -230 pp., Batavia.

Bock, C.; Pröschold, T. \& Krienitz, L. (2011): Updating the genus Dictyosphaerium and description of Mucidosphaerium gen. nov. (Trebouxiophyceae) based on morphological and molecular data. - J. Phycol. 47: 638-652

Buchheim, M. A.; Keller, A.; Koetschan, C.; Förster, F.; Merget, B. \& Wolf, M. (2011): Internal Transcribed Spacer 2 (nu ITS2 rRNA) sequence-structure phylogenetics: Towards an automated reconstruction of the green algal tree of life. - PLoS One 6: 2. e16931.

Chodat, R. (1913): Scenedesmus Meyen. - Monographies d'algues en culture pure matériaux pour la flore cryptogamique suisse 4: 13-85.

Chodat, R. (1926): Scenedesmus. Etude de génétique, de systematique expérimentale et d'hydrobiologie. (Schweiz.) Zeitschr. Hydrol. (Rev. d'Hydrol.) 3: $71-258$.

Comas, A. \& Komárek, J. (1984): Taxonomy and nomenclature of several species of Scenedesmus (Chlorellales)

Arch. Hydrobiol., Suppl. 67, Algological Studies 35: 135-157.

Corradi, M. G.; Gorbi, G. \& Bassi, M. (1995a): Hexavalent chromium induces gametogenesis in the freshwater alga Scenedesmus acutus. - Ecotox. Environm. Saf. 30: 106-110.

Corradi, M. G.; Gorbi, G.; Ricci, A.; Torelli, A. \& Bassi, M. (1995b): Chromium-induced sexual reproduction gives rise to a $\mathrm{Cr}$-tolerant progeny in Scenedesmus acutus. - Ecotox. Environm Saf. 32: 12-18.

Dzhambazov, B.; Mladenov, D.; Belkinova, D. \& Hegewald, E. (2001): Karyotype study of Scenedesmus regularis Svir. and $S$. pectinatus MeYen (Chlorophyta, Chlorococcales) in clonal cultures in vitro. - Arch. Hydrobiol., Suppl. 137, Algological Studies 101: $121-128$

Dzhambazov, B.; Belkinova, D. \& Mladenov, R. (2002a): Sind Scenedesmus obtusiusculus CHоD. und Scenedesmus obliquus (TuRp.) Kütz. (Chlorophyta, Chlorococcales) verschiedene Arten? - Arch. Hydrobiol., Suppl. 144, Algological Studies 106: 141-150.

Dzhambazov, B.; Mladenov, R. \& Belkinova, D. (2002b): Scenedesmus nygaardii Hub.-Pest. und Scenedesmus bernardii G.M. SмIтн (Chlorophyta, Chlorococcales) - zwei verschiedene Arten. - Arch. Hydrobiol., Suppl. 144, Algological Studies 106: 131 - 139.

Dzhambazov, B.; Belkinova, D. \& Mladenov, R. (2003): Karyotypic analysis of two algae species Scenedesmus incrassatulus BoHL and Scenedesmus antennatus BRÉB. (Chlorophyta, Chlorococcales). Hereditas 139: 35-40.

Dzhambazov, B.; Mladenov, R.; Teneva, I. \& Belkinova, D. (2006): Karyotypic differences and evolutionary tendencies of some species from the subgenus Obliquodesmus Mlad. of genus Scenedesmus Meyen (Chlorophyta, Chlorococcales). - J. Gen. 85: 39-44.

Echenique, R.; NúÑez-Avellaneda, M. \& Duque, S.R. (2004): Chlorococcales de la Amazonia Colombiana I: Chlorellaceae y Scenedesmaceae (Chlorococcales of the Colombia Amazonia I: Chlorellaceae and
Scenedesmaceae). - Caldasia 26: 37-51.

Elí́š, M.; NĚmcová, Y.; ŠKaloud, P.; Neustupa, J.; KaUfNerovÁ, V. \& ŠEJnOHOVÁ, L. (2010): Hylodesmus singaporensis gen. et sp. nov., a new autosporic subaerial green alga (Scenedesmaceae, Chlorophyta) from Singapore. - Intern. J. System. Evol. Microbiol. 60: $1224-1235$.

Eliáš, M.; Němcová, Y.; Škaloud, P.; Neustupa, J.; KAufNerová, V. \& ŠEJNOHOVÁ, L. (2011): Hylodesmus singaporensis gen. et sp. nov., a new autosporic subaerial green alga (Scenedesmaceae, Chlorophyta) from Singapore. Additional figures. - Intern. J. System. Evol. Microbiol.: http://ijs.sgmjournals.org/ content/60/5/1224/suppl/DC1

Fawley, M.W.; Fawley, K.P. \& Hegewald, E. (2011): Taxonomy of Desmodesmus serratus (Chlorophyceae, Chlorophyta) and related taxa on the basis of morphological and DNA sequence data. - Phycologia 50: 23-56

Hegewald, E. (1978): Eine neue Unterteilung der Gattung Scenedesmus Meyen. - Nova Hedw. 30: 343-376.

Hegewald, E. (1982): Taxonomisch-morphologische Untersuchungen von Scenedesmus-Isolaten aus Stammsammlungen. - Arch. Hydrobiol., Suppl. 60, Algological Studies 29: 375-406.

Hegewald, E. (1989): The Scenedesmus strains of the Culture Collection of the University of

Texas at Austin, Texas (UTEX). - Arch. Hydrobiol., Suppl. 82, Algological Studies 55: 153-189.

Hegewald, E. (1997): Taxonomy and phylogeny of Scenedesmus. - Algae 12: 235-246.

Hegewald, E.; Engelberg, K. \& Paschma, R. (1988): Beitrag zur Taxonomie der Gattung Scenedesmus, Subgenus Scenedesmus (Chlorophyceae). - Nova Hedw. 47: 497-533.

Hegewald, E.; Hindák, F. \& Schnepf, E. (1990): Studies on the genus Scenedesmus MeYen (Chlorophyta, Chlorococcales) from Southern India, with special reference to the cell wall ultrastructure. - Nova Hedw., Beih. 99: 1-75

Hegewald, E.; Krienitz, L. \& Schnepf, E. (1994): Studies on Scenedesmus costato-granulatus SkUja. - Nova Hedwigia 59: 97-127.

Hegewald, E. \& Silva, P. (1988): Annotated catalogue of Scenedesmus and nomenclaturally related genera including original descriptions and figures. - Bibl. Phycol. 80: 1- 587.

Hegewald, E. \& Schnepf, E. (1991): Scenedesmus abundans (KIrchn.) CHOD., an older name for Chlorella fusca SHIH. et Krauss. - Arch. Protistenk. 139: 133-176.

Hegewald E. \& An S.S. (1998): Scenedesmus schnepfii (Chlorophyta, Chlorococcales), a new species and its unicellular strain. - Biologia, Bratislava 53: 409-424.

Hegewald, E.; An, S.S. \& Tsarenko, P.M. (1998): Revision of Scenedesmus intermedius (Chlorococcales, Chlorophyta). - Algological Studies 88: 67-104.

Hegewald, E. \& Hanagata, N. (2000): Phylogenetic studies on Scenedesmaceae (Chlorophyta). - Algological Studies 100: 29-49.

Hegewald, E.; Schmidt, A.; Braband, A. \& Tsarenko, P. (2005): Revision of the Desmodesmus (Sphaeropleales, Scenedesmaceae) species with lateral spines. 2. The multi-spined to spineless taxa. - Arch. Hydrobiol., Suppl. 116, Algological Studies 
157: $1-38$.

Hegewald, E.; Stojkovic-Tadic, S.; Belkinova, D. \& Mladenov, D. (2001): Scenedesmus regularis Svir. (Chlorophyta, Chlorophyceae), its taxonomy and salt stress response. - Algological Studies 102: 147-159.

Hegewald, E. \& Wolf, M. (2003): Phylogenetic relationships of Scenedesmus and Acutodesmus (Chlorophyta, Chlorophyceae) as inferred from 18S rDNA and ITS-2 sequence comparisons. - Plant System. Evol. 241: 185-191.

Hegewald, E.; Wolf, M.; Keller, A.; Friedl, T. \& Krienitz, L. (2010): ITS2 sequence-structure phylogeny in the Scenedesmaceae with special reference to Coelastrum (Chlorophyta, Chlorophyceae), including the new genera Comasiella and Pectinodesmus. - Phycologia 49: 325-335.

Hepperle, D. (2004): SequentiX Alignment Editor. Distributed by Author.

Hindék, F. (1990): Studies on the chlorococcal algae (Chlorophyceae). V. - Biol. Práce 1990: 1- 225.

Holtmann, T. (1994): Revision des subgenus Acutodesmus, Gattung Scenedesmus (Grünalgen, Chlorophyceae) Vol. I, Vol. II (19 figs, 19 tables, 21 plates) [PhD thesis]. - 112 pp.,University Essen.

Holtmann, T.\& Hegewald, E. (1986): Der Einfluß von Nährlösungen auf die Variabilität von Isolaten der Gattung Scenedesmus, Untergattung Acutodesmus. Arch. Hydrobiol., Suppl. 73, Algological Studies 44: 365-380.

HortobÁgyi, T. (1960): Algen aus den Fischteichen von Buzsák II.: Scenedesmus-Arten. - Nova Hedwigia I: 345-381.

Huber-Pestalozzi, G. (1936): Phytoplankton aus Seen und Sümpfen Javas, gesammelt von Prof. C. SchröterZürich. - Ber. Schweiz. Bot. Gesell. 46: 131-168.

Huelsenbeck, J.P. \& Ronquist, F. (2001) MRBAYES: Bayesian inference of phylogenetic trees. Bioinformatics 17: 754-755.

JoвB, G. (2008). TREEFINDER version of October 2008. Munich, Germany. Distributed by the author at www. treefinder.de.

Johnson, J.L.; Fawley, M.W. \& Fawley, K.P. (2007): The diversity of Scenedesmus and Desmodesmus (Chlorophyceae) in Itasca State Park, Minnesota, USA. - Phycologia 46: $214-229$.

KAlinA, T. \& PunČOCHÁŘovÁ, M. (1987): Taxonomy of the subfamily Scotiellocystoideae Fотт 1976 (Chlorellaceae, Chlorophyceae). - Arch. Hydrobiol., Suppl. 73, Algological Studies 45: 473-521.

Keller, A.; Schleicher, T.; Schultz, J.; Müller, T.; Dandekar, T. \& Wolf, M. (2009): 5.8S-28S rRNA interaction and HMMbased ITS2 annotation. - Gene 430: 50-57.

Kessler, E.; Schafer, M.; Hummer, C.; Kloboucek, A. \& Huss, V.A.R. (1997): Physiological, biochemical, and molecular characters for the taxonomy of the subgenera of Scenedesmus (Chlorococcales, Chlorophyta). - Botanica Acta 110: 244-250.

KIRIAKOV, I.K. (1976): Vorhu njakoi morfologicni belezi na podrod Fusodesmus (CHOD.) KIRIAKOV nov. nom. ot rod Scenedesmus Meyen (Chlorococcales). - Sbornik Trudove na mladite naucni rabotnici I student 4: 197- 204.

KitschKe, M. (2001): Molekulargenetische Untersuchungen zur Diversität und Phylogenie von kokkalen
Grünalgen (Scenedesmaceae, Chlorophyta Chlorophyceae) [Ms thesis]. - 136 pp., University Göttingen.

KomÁrek, J. \& Fotт, B. (1983): Chlorophyceae (Grünalgen), Ordnung Chlorococcales. - In: Huber-Pestalozzi, G. (ed.): Die Binnengewässer. Das Phytoplankton des Süßwassers, 7. Teil, 1. Hälfte, vol. XVI. - 1044 pp., Schweizerbart, Stuttgart.

KrienITZ, L. (1987): Studien zur Morphologie und Taxonomie der Untergattung Acutodesmus (Chlorellales). Arch. Hydrobiol., Suppl. 78, Algological Studies 46: $1-37$.

Krienitz, L.; Hegewald, E.; Hepperle, D. \& Wolf, M. (2003): The systematics of coccoid green algae: 18S rRNA gene sequence data versus morphology. - Biologia 58: 437-446.

KrienItZ, L. \& WIRTH, M. (2006): The high content of polyunsaturated fatty acids in Nannochloropsis limnetica (Eustigmatophyceae) and its implication for food web interactions, freshwater aquaculture and biotechnology. - Limnologica 36: 204-210.

Lewis, L.A. \& Flechtner, V.R. (2004): Cryptic species of Scenedesmus (Chlorophyta) from desert soil communities of Western North America. - J. Phycol. 40: $1127-1137$.

Meyen, F.J.F. (1829): Beobachtungen über einige niedere Algenformen.--Verhandl. Kaiserl. Leopold.-Carolol. Akad. Naturf. 14: 769-778.

Ooshima, K. (1981): Taxonomic studies on Scenedesmus in Japan 1. On Scenedesmus acuminatus (LAG.) CHOD. and its varieties and S. javanensis CHoD. - Jap. J. Phycol. 29: 85-93.

Paschma, R. \& Hegewald, E. (1986): DNA base composition within the genus Scenedesmus (Chlorophyta). - Plant System. Evol. 153: 171-180.

Protist INFORMATION SERVER (19952010): http://protist.i.hosei.ac.jp/pdb/images/ chlorophyta/Scenedesmus/javanensis/index.html

PunčocháR̆ovÁ, M. \& Kalina, T. (1981): Taxonomy of the genus Scotiellopsis VInATZER (Chlorococcales, Chlorophyta). - Arch. Hydrobiol., Suppl. 60, Algological Studies 27: 119-147.

Rambaut, A. \& Drummond, A. (2007): Tracer v1.4. Available at http://beast.bio.ed.ac.uk/Tracer

Rodrigues, L.L.; Leite Sant'Anna, C. \& Tucci, A. (2010): Chlorophyceae das represas Billings (Braço Taquacetuba) e Guarapiranga, SP, Brasil (Chlorophyceae of Billings (Taquacetuba arm) and Guarapiranga reservoirs, SP, Brazil). - Rev. Brasil. Bot. 33: 247-264.

Silva, L. H. S. (1999): Fitoplâncton de um reservatório eutrófico (Lago Monte Alegre), Ribeirão Preto, São Paulo, Brasil. - Rev. Brasil. Biol. 59: 281-303.

Sмith, G.M. (1913): Tetradesmus, a new four-celled coenobic alga. - Bull. Torr. Bot. Club 40: 75-87.

SмiтH, G.M. (1916): A monograph of the algal genus Scenedesmus based upon based pure culture studies. - Trans. Wisc. Acad. Sci., Arts \& Lett. 18: 422-528, pl. 25-33.

Smith, G.M. (1920): Phytoplankton of the inland lakes of Wisconsin. - Wisc. Geol. Nat. Hist. Surv.,B ull. 57: 1-234.

Somerville, C. C.; Knight, I. T.; Straube, W. L. \& Colwell, R. R. (1989): Simple, Rapid Method for Direct Isolation of Nucleic-Acids from Aquatic Environments. - 
Appl. Envir. Microbiol. 55: 548-554.

Swofford, D.L. (2002): Phylogenetic analysis using parsimony (* and other methods), PAUP version $4.0 \mathrm{~b}$ 10. 2003.

Trainor, F. R. (1963): Zoospores in Scenedesmus obliquus. Science 142: 1673-4.

Trainor, F. R. (1964): Spine distribution in several Scenedesmus cultures. - Amer. J. Bot. 51: 995-1001.

TraINOR, F. R. (1996): Reproduction in Scenedesmus obliquus. - Algae 11: 183-201.

Trainor, F. R. \& Burg, C. A. (1965): Scenedesmus obliquus sexuality. - Science 148: 1094-1095.

Tsarenko, P.; Hegewald, E. \& Braband, A. (2006 „2005”): Scenedesmus-like algae of Ukraine. 1. Diversity and rare taxa from water bodies in Volyn Polissia. Algological Studies 118: 1-45.

Tsarenko, P.M. \& Petlevanny, O.A. (2001): Addition to the diversity of algae of Ukraine. - Algologia, unnumbered supplement: 1-130.

Tschaikner, A.; Ingolić, E.; Stoyneva, M. \& Gärtner, G. (2007): Autosporulation in the soil alga Coelastrella terrestris (Chlorophyta, Scenedesmaceae, Scenedesmoideae). - Phytol. Balc. 13: 29-34

TuRPIN, P.J.F. (1828): Aperçu organographique sur le nombre deux, considéré comme multiplicateur de quatre, huit, douze, seize, trente-deux et soixante-quatre dans la structure des végétaux d'un ordre inférieur. - Mém. Mus. Nat. d'Hist. Nat. [Paris] 16: 295-344, pl. 13.

Uherkovich, G. \& RaI, H. (1977): Zur Kenntnis des Phytoplanktons einiger Gewässer des Staates Elfenbeinküste (Afrika). I. Bouaké-Stausee. - Arch. Hydrobiol. 81: 233-258.

VAN HanNEn, E.J.; FInK, P. \& LÜRling, M. (2002): A revised secondary structure model for the internal transcribed spacer 2 of the green algae Scenedesmus and Desmodesmus and its implication for the phylogeny of these algae. - Europ. J. Phycol. 37: 203-208.

Vanormelingen, P.; Hegewald, E.; Braband, A.; KitschKe, M.; Friedl, T.; Sabbe, K. \& Vyverman, W. (2007): The systematics of a small spineless Desmodesmus taxon, D. costato-granulatus (Sphaeropleales, Chlorophyceae), based on ITS2 rDNA sequence analyses and cell wall morphology. - J. Phycol. 43: 378-396.
YAmagishi, T. (1992): Plankton algae in Taiwan (Formosa). - 253 pp., Uchida Rokakuho Publishing Co.,Tokio.

Yamagishi, T. \& AkiYama, M. (eds) (1995): Photomicrographs of the Freshwater Algae 15. - 56 pp., Uchida Rokakuho Publishing Co.

Supplementary material

the following supplementary material is available for this article:

Table S1. Strains sequenced for this study.

Table S2. ITS-data from GenBank: Species: revised names, in brackets former names. Strains: first number is the strain which was used for DNA analyses, in brackets the earlier or the later strain number.

Table S3. Number of base exchanges (ITS2) between Neodesmus, Dimorphococcus, Coelastrum, Colastrella, Verrucodesmus, Scenedesmus, Enallax, Comasiella and Chodatodesmus.

Table S4. Number of base exchanges (ITS2) between Pectinodesmus species.

Table S5. Number of base exchanges (ITS2) between Acutodesmus strains.

This material is available as part of the online article (http://fottea.czechphycology.cz/contents)

(C) Czech Phycological Society (2013)

Received Novenber 10, 2012

Accepted March 9, 2013 